ACTA THERIOLOGICA

Vol. 28, 22: $351-356,1983$

\title{
Topography and Structure of Hebenular Nuclei in Four Species of Insectivora
}

\section{Anna KRAWCZUK}

\begin{abstract}
Krawczuk A., 1983: Topography and structure of habenuler nuclei in four species of Insectivora. Acta theriol., 28, 22: 351-356 [With 1 Table \& Plates XI-XII]

A description is given of the topography, form and cell structure of habenular nuclei in four species of animals - Sorex araneus, Sorex minutus, Neomys fodiens and Talpa europaea, on the basis of paraffin cross-sections stained by the Nissl and Klüver-Barrera methods. The situation of habenular nuclei in these species does not exhibit differences in this respect from other mammals, but features characteristics of representatives of Insectivora can be seen in their form and cytoarchitectonic structure.

[Teachers Training College, Department of Zoology, Zolnierska 14, 10-561, Olsztyn, Poland]
\end{abstract}

\section{INTRODUCTION}

There are relatively few papers on the morphology and functions of the habenular nuclei in mammals in neuroanatomical literature so far published. The present studies, however, justify the conclusion that the role of the habenular nuclei is not limited to strictly olfactory functions and that their physiological importance is greater, but up to the present no satisfactory explanation has yet been provided. The functional importance of the habenular nuclei is indicated, inter alia, by their connection with the nerve centres of the mesencephalon, thalamus, globus pallidus, hippocampal gyrus, amygdaloid nucleus, interpeduncular nucleus, raphe nuclei, substantia nigra and with centres of the hypothalamus (Herkenham \& Nauta, 1979). Examination has so far been made of the habenular nuclei in representatives of Rodentia (Szteyn, 1968; Szteyn \& Dynowski, 1977; Winnicka \& Woroniecka, 1978; Herkenham \& Nauta, 1979; Meyer \& Ferres-Torres, 1981), Carnivora (Iwahori, 1977), Primates (Simmons, 1979, 1980, 1981) and domestic animals (Szteyn, 1967; Szteyn \& Welento, 1967; Welento, 1964). It can be seen from the foregoing that there are no data in literature on the structure of habenular nuclei in mammals of the order Insectivora.

The purpose of this study is to describe the topography and structure of habenular nuclei in four selected common insectivorous species. 


\section{MATERIAL AND METHODS}

The encephalon from 3 sexually mature common shrews (Sorex araneus Linnaeus, 1758), 3 pygmy shrews (Sorex minutus Linnaeus, 1766), 3 water shrews (Neomys fodiens (Pennant, 1771)) and 2 moles (Talpa europaea Linnaeus, 1758) was fixed in ethyl alcohol and formalin, embedded in paraffin and sectioned from the posterior into cross-sections $15 \mu \mathrm{m}$ thick. The sections were stained with Löffler's methylene blue by Nissl's method and with fast blue luxol and cresylite violet by the Klüver-Barrera's method. Consecutive sections were taken for examination.

\section{RESULTS}

Two agglomerations of cells occur in the habenular complex in the species of mammals examined: nucleus habenularis medialis and nucleus habenularis lateralis.

\section{Nucleus habenularis medialis (Hm)}

$\mathrm{Hm}$ of the insectivores is situated in the dorso-medial part of the rear part of the thalamus, in the medial part of the medullar stria. The nucleus is a band of cells distinctly separated from the neighbouring nerve centres, forming a convexity in the dorsal part of the wall of III ventricle. $\mathrm{Hm}$ is shortest in the pygmy shrew and longest in the mole (Table 1). The posterior pole of the nucleus appears at a slight distance backwards from the posterior margin of commisura habenularum. In cross-sections in shrews and the mole the posterior end of the nucleus is oval. In the water shrew the posterior part of $\mathrm{Hm}$ takes the form of an elongated group of cells which in a forwards direction acquire an oval outline and retain this shape throughout almost its whole length (Fig. 3). In shrews and the water shrew at the level of the anterior boundary of $1 / 5$ of the posterior part of $\mathrm{Hm}$ a band of fibres of the medullar stria separate the nucleus into two groups: dorso-lateral and ventro-medial, which disappear further to the front. In the central part the centre described in the common shrew takes the form of a rhomb with rounded angles (Fig. 1, Plate XI), and in the pygmy shrew - the shape of a trapezium (Fig. 2). In the mole the division of the nucleus takes place slightly later, and narrow groups of cells in the dorsal, ventral and lateral regions are separated from $\mathrm{Hm}$ by the medullary stria fibres. These groups reconnect with the nucleus near the anterior pole of $\mathrm{Hm}$. Nucleus habenularis medialis in the mole has in its central part the shape of a comma, the sharp end of which points downwards (Fig. 4, Plate XI). The anterior part of this centre again takes on the outline of an oval group of cells, which gradually disappears. The 
anterior pole of $\mathrm{Hm}$ in the water shrew is formed by cells arranged in the form of a ring, but in shrews in an irregular group of cells. It is only in the common shrew that short-lived divisions were found in the anterior part of the nucleus.

The cytoarchitectonic structure of nucleus habenularis medialis in insectivores exhibits certain specific differences (Table 1). $\mathrm{Hm}$ in the common shrew (Fig. 5, Plate XII) and water shrew (Fig. 7) is formed mainly by oval, rounded or fusiform cells. The number of multipolar cells is smaller. Oval and rounded cells predominate in nucleus habenularis medialis in the pygmy shrew (Fig. 6), but in the mole (Fig. 8) multipolar cells are in the majority. $\mathrm{Hm}$ in the mole exhibits distinct division into the dorsal part with small cells and ventral part with large cells. A large nucleus with intensively staining nucleolus occurs in the cells of nucleus habenularis medialis, and in the cell plasm there is a large amount of coarse-grained tigroid substance.

\section{Nucleus habenularis lateralis $(\mathrm{Hl})$}

The $\mathrm{Hl}$ of the mammals examined is situated in the dorsal region of the posterior part of the thalamus, laterally from $\mathrm{Hm}$ (Figs. 1-4). Nucleus lateralis is shorter (Table 1), less compact and not so distinctly separated from other structures of the thalamus as is nucleus medialis. In cross-sections the posterior pole of $\mathrm{Hl}$ in insectivores forms a small agglomeration of cells, which next take on the shape of a band lying near the ventro-lateral margin of $\mathrm{Hm}$. Further forwards $\mathrm{Hl}$ in common

Table 1

Morphometric and cytometric description of habenular nuclei in Insectivora (cell size based on 10 measurements).

Items Sorex araneus Sorex minutus Neomys fodiens Talpa eropaeua

Nuclenus habenularis medialis

$\begin{array}{lcccc}\text { Length, mm } & 0.9 & 0.7 & 0.9 & 1.3 \\ \text { Oval } & 4-10 ;++ & 4-11 ;+++ & 5-14 ;++ & 5-15 ;++ \\ \text { Fusiform } & 10-21 ;++ & 10-17 ;++ & 10-18 ;++ & 10-20 ;++ \\ \text { Multipolar } & 7-14 ;+ & 7-11 ;+ & 7-14 ;+ & 7-21 ;+++\end{array}$

Nucleus habenularis lateralis

Length, mm

Oval

$\begin{array}{ccc}0.5 & 0.6 & 0.7 \\ 8-21 ;++ & 10-18 ;++ & 10-20 ;+ \\ 10-25 ;++ & 14-21 ;++ & 14-21 ;++ \\ 10-21 ;+++ & 12-26 ;+++ & 14-25 ;+++\end{array}$

Multipolar

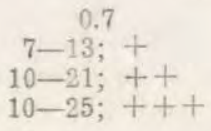

$10-21 ;+++$

$12-26 ;+++$

$14-25 ;+++$

Accepted three-degree scale of number of cells in a nucleus; + few; ++ large number; +++ very large number. Cell dimensions in $\mu \mathrm{m}$. 
shrews is oval in shape, in the pygmy shrew and mole - oval or ar: irregular group of cells, while in the water shrew the nucleus, after a shortlived division, takes on the shape of a rectangle. Short but repeated divisions of the nucleus occur in the common shrew also. The anterior part of $\mathrm{Hl}$ in the mole is formed by aggregations of closely distributed cells, between which there are loosely distributed neurons. In all insectivores the anterior pole of nucleus habenularis lateralis is formed by scattered cells not clearly separated from surrounding structures.

Nucleus habenularis lateralis in the common shrew (Fig. 9, Plate XII), water shrew (Fig. 11) and mole (Fig. 12, Plate XII) is formed by multipolar and fusiform cells and a small number of oval and rounded cells differing in the various species only in respect of dimensions (Table 1). The cell structure of $\mathrm{Hl}$ in the pygmy shrew (Fig. 10) is similar to the cell structure of this nucleus in the other insectivores, but far more oval and rounded cells occur in it and they are larger (Table 1). A large nucleus with deeply staining nucleolus occurs in the cells. The cell plasma contains a fairly large number of granules of tigroid matter.

\section{DISCUSSION}

The situation of nuclei habenulare in insectivores is similar to that in other representatives of Mammalia. Nucleus habenularis medialis is more strongly formed than nucleus habenularis lateralis. Only Szteyn (1967) found the reverse situation in sheep. In Insectivora $\mathrm{Hm}$ reaches further forwards then $\mathrm{Hl}$ and - with the exception of the water shrew - backwards. A similar situation was found by Simmons $(1980,1981)$ in Prosimiae, Szteyn \& Dynowski (1977) in the beaver and Szteyn (1968) in nutria. It must be emphasized that $\mathrm{Hm}$ in the mole reaches further forward not only in comparison with other insectivores, but also in comparison with nutria, in which this nucleus is relatively strongly formed (Szteyn, 1968). This fact may provide evidence of the better development of certain parts of the rhinencephalon in the mole than in other insectivores and also in representatives of Rodentia. In the mammals examined the fibres of the medullar stria separate groups of cells ir Hm: in the mole - lateral, dorsal and ventral, and in the remaining three species - the dorso-lateral group. This division of the nucleus examined has not been described in other mammals. Only Szteyn (1967) in the sheep, Szteyn \& Welento (1967) in the goat, Gurdijan (cited after Szteyn, 1967) in the rat and Tsai (cited after Szteyn, 1967) in the opossum divided $\mathrm{Hm}$ into dorso-medial and ventro-medial parts. 
In insectivores, as in the majority of the representatives of Mammalia examined, $\mathrm{Hl}$ is a homogeneous band of cells. Only Herkenham \& Nauta (1979) divided $\mathrm{Hl}$ in the rat into medial and lateral parts, on the basis of the system of different fibres and on account of the cytoarchitectonics of the centre examined.

Comparison of the cell structure of nucleus habenularis in Insectivora and other mammals reveals certain differences. In nucleus habenularis medialis of Soricidae densely distributed small oval and rounded cells predominate. A similar situation was found in the cat (Iwahori, 1977), laboratory mice (Meyer \& Ferres-Torres, 1981), nutria (Szteyn, 1968), rat (Herkenham \& Nauta, 1979) and Prosimiae (Simmons, 1980). It is only in the mole that $\mathrm{Hm}$ is formed by multipolar cells and a small number of fusiform and rounded cells, this being similar to the cell structure of the analogical centre in the sheep (Szteyn, 1967), goat (Szteyn \& Welento, 1967), pig (Welento, 1964) and beaver (Szteyn \& Dynowski, 1977). Nucleus habenularis lateralis in insectivores is formed chiefly by multipolar cells. It is only in the $\mathrm{Hl}$ of pygmy shrews that the are far more rounded and oval cells than in other insectivores and the beaver (Szteyn \& Dynowski, 1977). In Insectivora the majority of $\mathrm{Hl}$ cells are larger than cells in $\mathrm{Hm}$. This agrees with observations of other mammals, with the exception of the rat, in which Gurdijan \& Craige (cited after Szteyn, 1968) found the reverse situation. The results of studies by these last authors, however, were not confirmed by the observations made by Herkenham \& Nauta (1979) and Winnicka \& Woroniecka (1978). The cells of nucleus habenularis lateralis in insectivores do not stain so deeply as the cells of nucleus habenularis medialis, which agrees with observations of other mammals, e.g. the sheep, nutria (Szteyn, 1967, 1968) and goat (Szteyn \& Welento, 1967).

The absence of distinct differences in formation and cell structure of habenular nuclei in Sorex araneus, Sorex minutus and Neomys fodiens is probably due to the closer phylogenetic relation of these mammals (family Soricidae) and their similar way of life, as compared with the mole. The relatively strongly formed habenular nuclei in Insectivora is evidence of the well developed sense of smell in these animals.

\section{REFERENCES}

1. Herkenham M. \& Nauta W. J. H., 1979: Efferent connections of the habenular nuclei in the rat. J. comp. Neurol., 187: 19-47.

2. Iwahori N., 1977: A Golgi study on the habenular nucleus of the cat. J. comp. Neurol., 171: 319-344.

3. Meyer G. \& Ferres-Torres R., 1981: Zur Dendritenstruktur der Habenula in der Albinomaus. J. Hirnforsch., 22: 153-159. 
4. Simmons R. M. T., 1979: The diencephalon of Ptilocercus lowii (pen-tailed treeshrew). J. Hirnforsch., 20: 69-92.

5. Simmons R. M. T., 1980: The morphology of the diencephalon in the Prosimii. II. The Lemuroidea and Lorisoidea. Part II. Epithalamus, subthalamus and hypothalamus. J. Hirnforsch., 21: 493-514.

6. Simmons R. M. T., 1981: Bearing of the diencephalon on the taxonomic status of the Tupaioidea. J. Hirnforsch., 22: 129-152.

7. Szteyn S., 1967: Topografia i budowa jąder wędzidelka (nuclei habenulae) owcy. Pol. Archwm wet., 10: 685-692.

8. Szteyn S., 1968: Jądra wędzidelka (nuclei habenulae) nutrii, Folia morph., 27: 33-39.

9. Szteyn S. \& Dynowski J., 1977: The topography and structure of the habenular nuclei of the European beaver. Acta theriol., 22: 371-376.

10. Szteyn S. \& Welento J., 1967: Topografia i budowa jąder wędzidełka (nuclei habenulae) kozy. Folia morph., 26: 73-78.

11. Welento J., 1964: Budowa i topografia jąder międzymózgowia świni. Annls, Univ. M. Curie-Skłodowska, DD, 19: 125-172.

12. Woroniecka G. \& Winnicka M. M., 1978: Comparative morphologic and histochemical study on the some species of mammals of the family Muridae. Folia morph., 37: 275-281.

Accepted, May 23, 1983.

Anna KRAWCZUK

\section{TOPOGRAFIA I BUDCWA JĄDER WĘDZIDEEKA \\ U CZTERECH GATUNKOW OWADOZERNYCH}

\section{Streszczenie}

W pracy przedstawiono wyniki porównawczych badań nad polożeniem i morfologią jąder wędzidełka u czterech gatunków owadożernych: Sorex araneus, Sorex minutus, Neomys fodiens i Talpa europaea. Parafinowe skrawki poprzeczne o grubości $15 \mu \mathrm{m}$ z mózgowi dojrzałych płciowo zwierząt barwiono metodami Nissla i Klüvera-Barrera. W kompleksie wędzidełka wyodrębniono i opisano dwie aglomeracje komórkowe: jądro wędzidełka przyśrodkowe (nucleus habenularis medialis) i jądro wędzidelka boczne (nucleus habenularis lateralis). Strwierdzono, że nucleus habenularis medialis jest znacznie silniej wykształcone niż nucleus habenularis lateralis, które u owadożernych jest krótsze i mniej zwarte niż jądro przyśrodkowe. Położenie jąder wędzidełka u badanych gatunków nie wykazuje różnic w porównaniu $\mathrm{z}$ innymi ssakami, natomiast $\mathrm{w}$ ich uksztaltowaniu i cytoarchitektonice widoczne są pewne charakterystyczne cechy gatunkowe. 

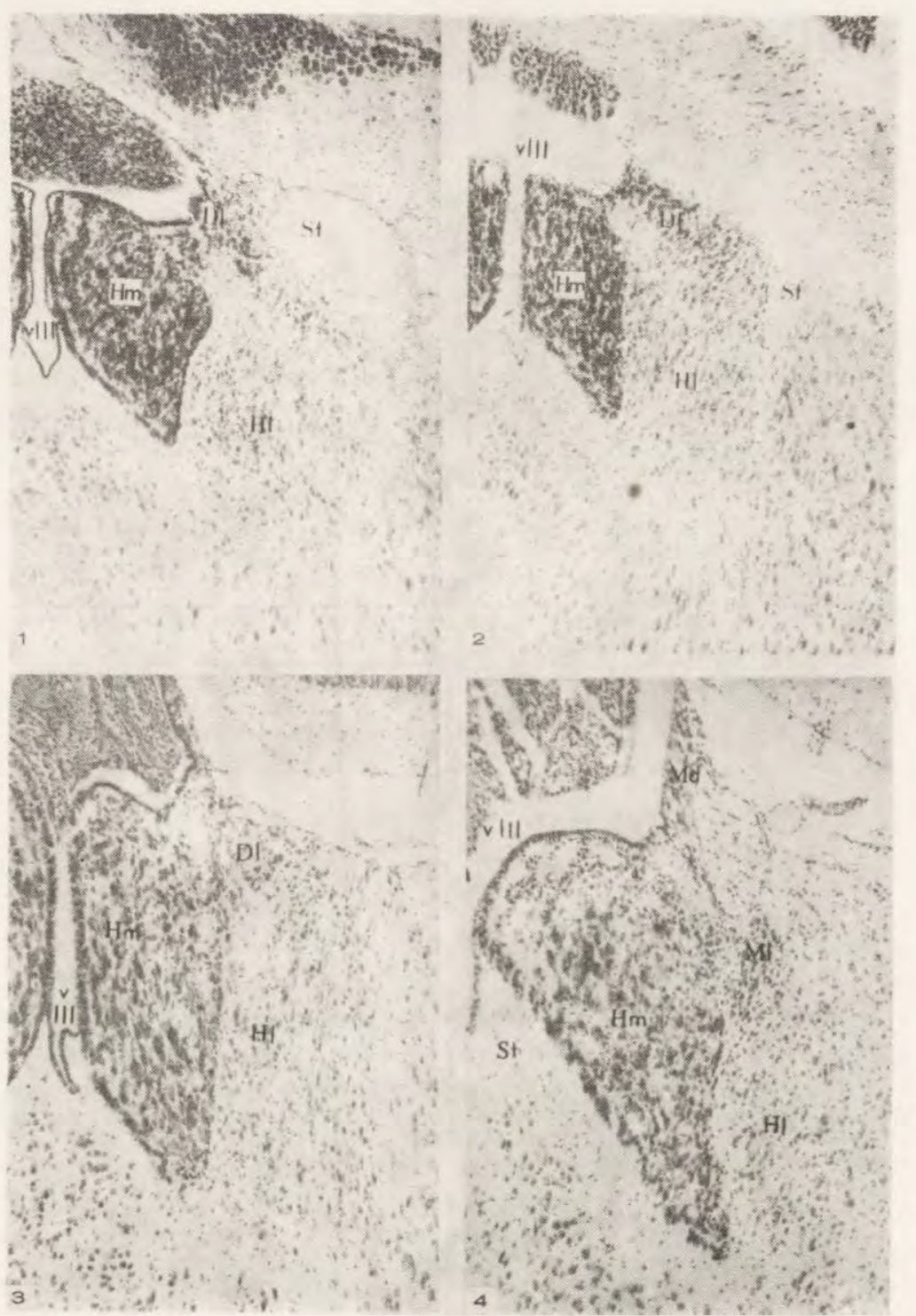

Plate XI

Rig. 1. Cross-section of diencephalon in the common shrew at the level of the medial part of nucleus habenularis medialis. Magn. 100X

Fig. 2. Cross-section of diencephalon of the pygmy shrew at the level of the medial part of nucleus habenularis medialis. Magn. $100 \times$

Fig. 3. Cross-section of the diencephalon of the water shrew at the level of the medial part of nucleus habenularis medialis. Magn. $100 \times$

Fig. 4. Cross-section of diencephalon in the mole at the level of the medial part of nucleus habenularis medialis. Magn. 150X. 


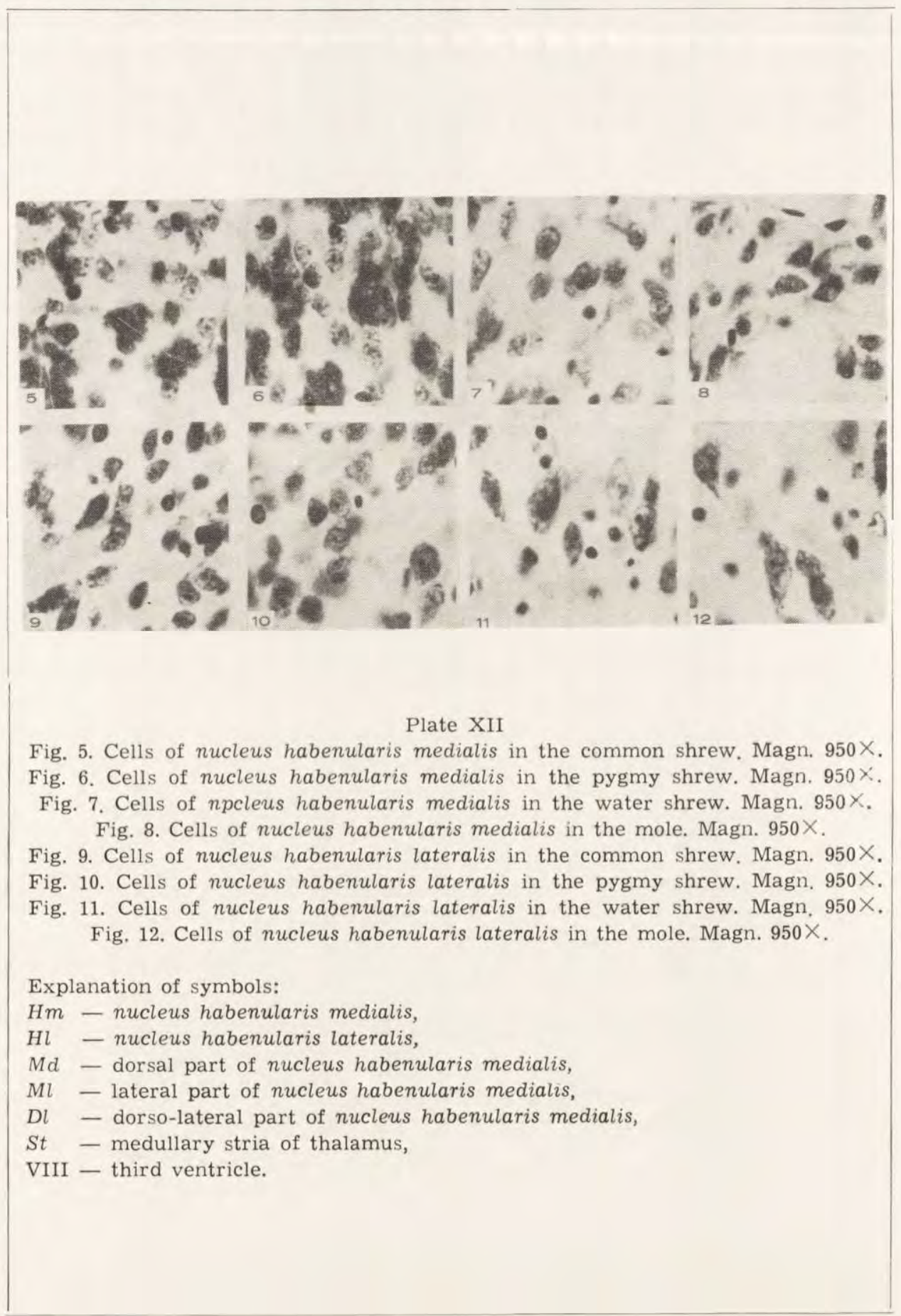

